University of California, Hastings College of the Law UC Hastings Scholarship Repository

Faculty Scholarship

2001

\title{
Confronting the Future: Coping with Discovery of Electronic Material
}

Richard L. Marcus

UC Hastings College of the Law, marcusr@uchastings.edu

Follow this and additional works at: http://repository.uchastings.edu/faculty_scholarship

Part of the Civil Procedure Commons

\section{Recommended Citation}

Richard L. Marcus, Confronting the Future: Coping with Discovery of Electronic Material, 64 Law \& Contemp. Probs. 253 (2001). Available at: http://repository.uchastings.edu/faculty_scholarship/454

This Article is brought to you for free and open access by UC Hastings Scholarship Repository. It has been accepted for inclusion in Faculty Scholarship by an authorized administrator of UC Hastings Scholarship Repository. For more information, please contact marcusc@uchastings.edu. 


\section{Faculty Publications \\ UC Hastings College of the Law Library}

Author: Richard L. Marcus

Source: $\quad$ Law \& Contemporary Problems

Citation: $\quad 64$ Law \& Contemp. Probs. 253 (2001).

Title: $\quad$ Confronting the Future: Coping with Discovery of Electronic Material

Originally published in LAW \& CONTEMPORARY PROBLEMS. This article is reprinted with permission from LAW \& CONTEMPORARY PROBLEMS and Duke Law School. 


\title{
CONFRONTING THE FUTURE: COPING WITH DISCOVERY OF ELECTRONIC MATERIAL
}

\author{
RICHARD L. MARCUS* \\ I \\ INTRODUCTION
}

It is always unpleasant to be caught on the wrong side of a generation gap, and people my age may be on the wrong side of the computer generation gap. The title of this article may be a misnomer, for, according to our juniors, what we need to do regarding the discovery of electronic material is to confront the present. Although the pace of change in computer developments is arresting, and the future undoubtedly holds more change, the reality is that the discovery of material stored on computers is already important. Particularly in complex cases-the focus of this article-discovery of electronic material is increasingly pervasive and central to the legal outcomes reached in the new millennium.

The question for the present is whether this new development calls for a reconsideration of our rules or methods of discovery. Ideally, a procedural system should be designed so that it can cope with technological (and other) developments without a major overhaul, and perhaps without any revision. For instance, in 1999, the Supreme Court dealt with the thorny problem of interpreting a 1949 amendment to the removal statute' in a case involving a "courtesy copy" of the complaint sent by fax. ${ }^{2}$ The court noted that Congress could not have foreseen the use of this technology when it amended the statute in

Copyright $\odot 2001$ by Richard L. Marcus

This article is also available at http://www.law.duke.edu/journals/64LCPMarcus

* Horace O. Coil ('57) Chair in Litigation, University of California, Hastings College of the Law.

Since 1996, I have served as Special Reporter to the Advisory Committee on Civil Rules in its review of the discovery rules. None of the points I make in this article, however, represents the views of the Advisory Committee or any of its members. A version of this article was presented at the Complex Litigation conference co-sponsored by Duke University and The Institute for Law and Economic Policy in Naples, Florida, on April 15, 2000, and the final version of the article was completed in August 2000. It describes ongoing examination of these issues by the Advisory Committee, and may not reflect all of the developments after August 2000. I am indebted to Vince Moyer of the Hastings Law Library for assistance in locating source material.

1. 28 U.S.C. $\S 1446$ (1994).

2. See Murphy Bros., Inc. v. Michetti Pipe Stringing, Inc., 526 U.S. 344, 347-48 (1999) (holding that the time to remove does not start to run until formal service of the complaint, despite the fact that 28 U.S.C. $\$ 1446$ (b) (1994) states that the time starts to run from "the receipt by the defendant, through service or otherwise, of a copy of the initial pleading"). 
1949 but did not find that fact critical to interpreting the statute suitably for the era of faxed communications. ${ }^{3}$

The question whether the advent of the Internet generation calls for a reexamination of other procedural techniques and rules has divided scholars. Although the Supreme Court has noted that the Internet is "a unique and wholly new medium of worldwide human communication," that does not mean that existing doctrines governing the limits of personal jurisdiction, for example, must be revised to cope with the new technology. Thus, some scholars argue that personal jurisdiction issues raised by Internet activity can be readily analyzed under the existing legal rules, ${ }^{5}$ while others see the Internet as upsetting the apple cart of contemporary personal jurisdiction rules. ${ }^{6}$

This article addresses similar issues about the rules governing discovery. It first sketches the background of the current rules, for this is not the first time someone has argued that the discovery rules are no longer suitable for the challenges of contemporary discovery, particularly in complex cases. The article then examines the ways in which the discovery of electronically stored materials might present qualitatively different problems from those raised by the discovery of hard copy materials. Against that background, it surveys possible courses of action, by rule amendment or otherwise, and concludes that no clear solution has yet emerged. Indeed, as members of the generation that has seen the most vigorous challenge to unfettered discovery, we might conclude that there is really no generation gap because the types of discovery problems that

3. See id. at $353 \mathrm{n} .5$ (noting that even the photocopy machine was not on the scene at the time Congress adopted the statute in question).

4. Reno v. A.C.L.U., 521 U.S. 844, 850 (quoting A.C.L.U. v. Reno, 929 F. Supp. 824, 843 (1997)).

5. See Allan Stein, The Unexceptional Problem of Jurisdiction in Cyberspace, 32 INT'L LAW. 1167, 1180 (1998):

$[T]$ he Internet is no different from the myriad of ways that people from one place injure people in other places.... Since the replacement of strict territorialism [in personal jurisdiction analysis] ... such interstate activity no longer confounds the courts. There is a rich and complex body of law to test the legitimacy of sovereign claims to regulate and redress interstate claims.

6. See, e.g., Martin H. Redish, Of New Wine in Old Bottles: Personal Jurisdiction, the Internet, and The Nature of Constitutional Evolution, 38 JURIMETRICS 575 (1998). Professor Redish argues that the purposeful availment standard that the Supreme Court has developed over the past quarter century to limit exercises of personal jurisdiction does not work in the era of the Internet.

[B]ecause of the dramatic and unique ease with which those out-of-staters may make use of the Internet to inflict such harm, it will often be impossible realistically to characterize their activities as the purposeful availment of the jurisdiction's benefits and privileges, i.e., the conscious decision affirmatively to connect oneself with the forum state for the purpose of acquiring benefits and privileges from that state. Use of this standard will therefore effectively prevent individual states from protecting their citizens against Internet harm. At least in the context of the Internet, then, the purposeful availment test fails the traditional utilitarian calculus of procedural due process, which seeks to draw an appropriate balance between the competing interests of state and litigant.

Id. at 580 . 
arise with the new technology are analogous to those presented by hard copy discovery.

\section{THE DISCOVERY REVOLUTION AND ITS WAKE}

As Professor Stephen N. Subrin detailed in 1998, the adoption of the discovery provisions of the Federal Rules of Civil Procedure (the "Federal Rules" or the "Rules") in 1938 accomplished a "revolution" in discovery. ${ }^{8}$ Although pieces of the Federal Rules' discovery apparatus can be found in prior systems in the United States or in England, no prior system gave litigants such a variety of discovery tools, or the ability to use them so vigorously without judicial oversight. ${ }^{9}$

A prime motivating factor behind this revolution was the assumption articulated by the Supreme Court in Hickman v. Taylor" in 1947: "Mutual knowledge of all the relevant facts gathered by both parties is essential to proper litigation." By then, the federal bench seemingly had absorbed the new ethos; the lower court in Hickman thus observed that "the [Federal] Rules probably go further than any State practice." ${ }^{12}$ By the 1950s, Charles Clark, the prime author of the Federal Rules, acknowledged that the Federal Rules' discovery system "had no counterpart" at the time it was proposed..$^{13}$ Counterparts, however, soon emerged. Not only did many states adopt rules modeled on the Federal Rules, but others liberalized their existing discovery provisions.

The revolution in rules led to a revolution in attitudes. By the 1960s, a comprehensive study of discovery undertaken by Columbia University found that "[d]iscovery has become an integral part of litigation." ${ }^{14}$ More recently, Professor Hazard concluded that "[b]road discovery is thus not a mere procedural

7. At the outset, however, it should be emphasized that, although the Advisory Committee on Civil Rules has been studying these issues, it has not identified, or even considered, any specific solutions to such problems as may exist.

8. See Stephen N. Subrin, Fishing Expeditions Allowed: The Historical Background of the 1938 Federal Discovery Rules, 39 B.C. L. REV. 691, 734 (1998) (referring to "the discovery revolution begun by the Federal Rules").

9. See id. at 719 :

If one adds up all of the types of discovery permitted in individual state courts, one finds some precursors to what later became discovery under the Federal Rules; but ... no one state allowed the total panoply of devices. Moreover, the Federal Rules, as they became law in 1938, eliminated features of discovery that in some states had curtailed the scope of discovery and the breadth of its use.

10. 329 U.S. 495 (1947).

11. Id. at 507 .

12. Hickman v. Taylor, 153 F.2d 212, 217 (3d Cir. 1945), aff'd, 329 U.S. 495 (1947).

13. Charles E. Clark, Edson Sunderland and the Federal Rules of Civil Procedure, $58 \mathrm{MICH}$. L. REV. 6, 11 (1959). Note that when the rules were proposed, the chairman of the drafting committee said that "[r]ules as liberal as those we have proposed have been in use in the English courts for many years. Similar systems are in effect in some States of the Union." Subrin, supra note 8, at 725-26. Professor Subrin noted, however, that this assertion was "an exaggeration." Id. at 726.

14. William A. Glaser, Pretrial Discovery and THE AdVersary SySTEM 51 (1968). 
rule. Rather it has become, at least for our era, a procedural institution perhaps of virtually constitutional foundation." 1 's

Pendulums swing both ways, however, and the American embrace of broad discovery reached its zenith with the 1970 amendments. Since that time, revisions have been mainly in the direction of containment-reining in aspects of discovery thought to be undesirable without retreating from the central principle of full disclosure of important information. ${ }^{16}$ It is debatable whether there was a pressing need for reform over the past quarter century. Many contended that the concerns advanced to justify the changes were overblown, but that is pertinent to this study only as an indication of the level of demonstrated problems necessary to warrant substantial rule revisions. The retrenchment effort began with the amendments adopted in 1980 and 1983 and was fortified by the amendments adopted in 1993. It was carried forward in the modest package of amendments recently approved by the Supreme Court. ${ }^{17}$ For purposes of the current topic, two themes should be mentioned: the principle of proportionality and quantitative limits on discovery.

The background for these is a substantial retreat from the party-control model that was a hallmark of the Rules' original discovery revolution. Before 1938, even where discovery could be obtained, it usually required some advance judicial authorization. The Rules disposed of most of these requirements. Beginning in the 1970s, however, concern about the unfettered use of discovery mounted. Attorneys sought "adult supervision" from judges to control discovery behavior. ${ }^{18}$ Beginning in 1983, the Rules tried to provide a framework for that activity. The 1983 amendments to Rule 16 directed judges to undertake some early management of most civil cases ${ }^{19}$ and the Civil Justice Reform Act of 1990 sought to promote that activity further ${ }^{20}$ In 1993, further amendments added the Rule 26(f) discovery conference, requiring parties to produce a discovery plan that is to be submitted to the judge before the Rule 16 scheduling order is entered. ${ }^{21}$ The 2000 discovery amendments are designed to further increase judicial control. ${ }^{22}$

A central conceptual feature of this judicial supervision is the proportionality principle, added in 1983. At that time, it was touted as "a 180-degree shift"

15. Geoffrey C. Hazard, From Whom No Secrets Are Kept, 76 TEX. L. REV. 1665, 1694 (1998).

16. For a chronicle of these developments, see Richard L. Marcus, Discovery Containment Redux, 39 B.C. L. REV. 747 (1998).

17. See Amendments to the Federal Rules of Civil Procedure, Federal Rules of Evidence, Federal Rules of Criminal Procedure, and Federal Rules of Bankruptcy Procedure, 192 F.R.D. 340, 376-97 (2000).

18. See Marcus, supra note 16 , at 781-82.

19. See FED. R. CIV. P. 16 advisory committee's note to 1983 amendment.

20. See 28 U.S.C. $\$ \S 471-82(1994)$.

21. See FED. R. CIV. P. 26(f).

22. See Amendments to the Federal Rules of Civil Procedure, supra note 17, at 389 (Committee Note to amendments to Rule 26(b)(1)) ("The amendment is designed to involve the court more actively in regulating the breadth of sweeping or contentious discovery."). 
in the orientation of the discovery rules. ${ }^{23}$ It was said that the objective was to "superimpos[e] the concept of proportionality on all behavior in the discovery arena." ${ }^{24}$ But the sea change did not occur. "[T] he amendment itself seems to have created only a ripple in the caselaw, although some courts now acknowledge that it is clearer than it was before that they should take responsibility for the amount of discovery in cases they manage. ${ }^{, 25}$ Given the repeated expressions of concern about the burdens imposed by the discovery of electronic material, this principle might find its application as a method for brokering requests for the discovery of electronic material.

The experience to date with the proportionality principle gives reason for caution, however. It can be seen as a hard-edged measure potentially causing a pervasive recalibration of discovery requests. Viewing it that way, two economists recently proposed that the Rules be changed to treat as "abusive" any discovery request that does not promise to increase the value of the claim or defense asserted by more than the cost of responding to the request. ${ }^{26}$ In part, this suggestion rests on a fundamental misunderstanding of the American attitude toward who should bear the cost of discovery. ${ }^{27}$ Furthermore, it displays undue confidence about the application of this sort of calculus. In reality, even economic analysis reveals that this sort of approach would not yield a socially desirable level of discovery. ${ }^{28}$ It is also difficult to find a ready set of values to apply in this sort of comparative analysis. ${ }^{29}$ Moreover, even a judge who feels

23. See Arthur R. Miller, The August 1983 Amendments to the Federal Rules of Civil Procedure: Promoting Effective Case Management and Lawyer Responsibility 32-33 (1983) (describing objectives of 1983 amendments).

24. In re Convergent Tech. Sec. Litig., 108 F.R.D. 328, 331 (N.D. Cal. 1985).

25. 8 Charles alan Wright et al., Federal Practice \& Procedure $\$ 2008.1$, at 121 (2d ed. 1994).

26. See Robert D. Cooter \& Daniel L. Rubinfeld, Reforming the New Discovery Rules, 84 GEO. L.J. 61, 63 (1995).

27. See Richard L. Marcus, Retooling American Discovery for the Twenty-First Century: Toward a New World Order?, 7 Tulane J. INT'L \& COMP. L. 153, 177-78 (1999) (explaining that there are fundamental questions about requiring parties to bear their opponents' discovery response costs, that doing so raises administrative difficulties, and that cost-shifting of some sorts may be beyond the authority of the Advisory Committee).

28. See Bruce L. Hay, Civil Discovery: Its Effects and Optimal Scope, 23 J. LEGAL STUD. 481 (1994) (arguing that the Cooter-Rubinfeld proposal is flawed); see also Edward H. Cooper, Discovery Cost Allocation: Comment on Cooter and Rubinfeld, 23 J. LEGAL STUD. 465 (1994) (questioning the premises of the Cooter-Rubinfeld proposal).

29. See Edward F. Sherman \& Stephen Kinnard, Federal Court Discovery in the '80s-Making the Rules Work, 95 F.R.D. 245, 276 (1982). On this point, consider the following observations at the time the proportionality principle was first proposed for the rules:

The list of circumstances [for limiting discovery on proportionality grounds] invokes costbenefit principles which contemplate both achieving an optimal level of discovery beyond which additional discovery would not be cost-effective and restricting discovery when the dollar amount or values at stake are low. ...

A potential difficulty with this approach is in finding principled criteria for differentiating between various types of cases. What values should be used in deciding whether, for example, the plaintiff in a $\$ 10,000$ personal injury case should be limited in the number of depositions he may take, or the plaintiff seeking reinstatement in an employment discrimination case should be prohibited from discovering documents only tangentially related to the claim, or the 
firmly in command of those values may find it difficult to determine how they should be applied in a given case. ${ }^{30}$ Accordingly, although the generalized concept of proportionality is sensible and central, the actual application of the idea is likely to be difficult even in familiar areas. Carrying it over to new technology presents additional challenges.

The other technique that has emerged and is inconsistent with the tailored management that adult supervision envisions is an effort to place, at least presumptively, numerical or similarly quantitative limits on discovery. This approach was devised to relieve the court of the burden of designing limits for specific cases and to give the parties more definite information about what they can expect to obtain. This sort of limitation may be anathema to the Rules' revolution, ${ }^{31}$ but the 1993 amendments adopted numerical limitations for depositions and interrogatories. The 2000 Amendments carry this further with a presumptive durational limitation for depositions.

\section{III}

\section{THE RISING CONCERN ABOUT DISCOVERY OF COMPUTERIZED MATERIAL- ARE THESE PROBLEMS REALLY NEW?}

"It may well be that Judge Charles E. Clark and the framers of the Federal Rules of Civil Procedure could not foresee the computer age." ${ }^{32}$ By the 1960s, however, the rule-makers began to consider the need for discovery of computerized material, and Rule 34 was amended in 1970 to include "data compilations from which information can be obtained." ${ }^{33}$ Discovery of such material began to become important in the decade or so after that. By 1985, one district judge wrote that "[c]omputers have become so commonplace that most court battles now involve discovery of some type of computer-stored information." ${ }^{34}$ Rule 26(a)(1)(B)'s initial disclosure requirement, added in 1993, also requires disclosure of "data compilations." 35 The Manual for Complex Litigation affirms that "[c]omputerized data have become commonplace in litigation."

This is hardly the first technological development that has had a major impact on discovery. Reflect for a moment on the technological aspects of law

\footnotetext{
defendant in a $\$ 10,000,000$ product liability case should be allowed to require answers to voId.

luminous interrogatories involving the most searching details of the plaintiff's past life?

30. See Patrick E. Higginbotham, Discovery Management Considerations in Antitrust Cases, 51 ANTITRUST L.J. 231, 236 (1982) (explaining difficulties a judge has in determining whether discovery is disproportional in a specific instance).

31. The principal author of the federal discovery rules, Professor Edson Sunderland, "thought that numeric limits on interrogatories were arbitrary; they were obviously not consistent with the wide-open discovery he favored." Subrin, supra note 8, at 723.

32. National Union Elec. Corp. v. Matsushita Elec. Indus. Co., 494 F. Supp. 1257, 1262 (E.D. Pa. 1980).

33. Fed. R. Civ. P. 34.

34. Bills v. Kennecott Corp., 108 F.R.D. 459, 462 (D. Utah 1985).

35. FED. R. CIV. P. 26(a)(1)(B).

36. Federal Judicial Ctr., Manual For Complex Litigation (ThIRD) § 21.446 (1995).
} 
practice in the 1930s, when the Federal Rules were drafted. Not only was there no Internet, there was also no word-processing. Even electric typewriters did not exist, and the photocopier had not been developed. Long distance telephone calls could not be dialed directly either, and there was no commercial jet travel. Nonetheless, by and large the discovery rules have adapted to all of these technological changes. ${ }^{37}$ Has the advent of computers and the Internet caused a change of a different magnitude or importance to discovery practices?

What we confront, then, is the risk of thinking that we need new rules when the present ones are adequate. A few years ago, for example, Judge Frank Easterbrook lampooned efforts to develop special law school curricular offerings styled "the Law of Cyberspace," claiming that this effort was akin to developing courses on "the Law of the Horse."38 Although cases about horses abound, they are not significantly different from cases that involve similar legal principles but are not about horses. Accordingly, the curriculum should focus only on topics of general applicability, and that does not include courses about computers and the law.

Judge Easterbrook's theme can be applied to the current topic. Like computers, the horse had a pervasive effect on society. The Great Wall of China, for instance, was built to respond to the threat of nomadic tribes on horses. ${ }^{39}$ The fact that the introduction of the horse was a "technological" breakthrough, however, does not mean that it called for a new set of legal rules. Some technological developments, like the introduction of the car, do require new legal rules. ${ }^{40}$ The present challenge is to determine whether new rules for discovery are needed to deal with this new technology.

In the last few years, the level of stated concern about this new form of discovery has mounted considerably. Some speak of "trying to stay ahead of the avalanche." growing use of the Internet and related communicational uses of computers and the escalating importance of such communications in lawsuits. As an article in the National Law Journal declared in 1997, "[e]-mail is the hottest topic in dis-

37. One slow-moving counter-example is the delayed adoption of the right to use videotaping to record a deposition. Despite technological advances, the inclusion of that option in the Rules took many years.

38. Frank H. Easterbrook, Cyberspace and the Law of the Horse, 1996 U. CHI. LEGAL F. 207. For a reaction to Easterbrook's curricular point, see Lawrence Lessig, The Law of the Horse: What Cyberlaw Might Teach, 113 HARV. L. REV. 501 (1999).

39. See ARTHUR Waldron, ThE GREAT WALl of CHINA: From History TO MYTH 30-51 (1990). The nomadic horsemen had a "powerful military advantage" given that the horse was "the most formidable single factor of Inner Asian military power" until modern weaponry was developed. Id. at 34 (quoting Denis Sinor, The Inner Asian Warriors, 101 J. AMER. ORIENTAL SOC'Y 133, 137 (1981)).

40. In regard to place of suit, for example, Olberding v. Illinois Central Railway Co., 346 U.S. 338 (1953), emphasized "the inroad which the automobile has made on the decision of Pennoyer $v$. Neff." Id. at 341. Similarly, dram shop liability laws and laws placing liability for accidents on car owners who loan their cars to bad drivers suggest that new legal provisions were necessary to deal with this technological development.

41. Alfred W. Cortese, Jr. \& Edward C. Wolfe, Electronic Discovery: Problems and Solutions, MET. CORP. COUNSEl, Apr. 2000, at 37. 
covery disputes." ${ }^{42}$ For lawyers, the professional literature on the discovery of these materials has exploded. ${ }^{43}$ At least two books have emerged on these issues, ${ }^{44}$ and law school casebooks are beginning to address them as well. ${ }^{45}$ Continuing legal education programs on the subject also abound. ${ }^{46}$ The trial of the government's antitrust action against Microsoft brought the use of e-mails as evidence to the attention of those beyond the legal profession. ${ }^{47}$ Thus, growing awareness of the value of discovering electronic communications, especially email, has fueled this burst of interest. ${ }^{48}$

The focus of this article is whether, particularly in terms of the provisions of the Rules, we should conclude that "electronic evidence is intrinsically different from paper evidence in ways that become important to the analysis of discovery disputes." Although a preliminary evaluation compels no absolute answers, it does suggest that attention should focus on a variety of possible distinctions between hard copy discovery and the discovery of electronic materials. Some of those distinctions are explored below.

\section{A. Computers Could Reduce the Burden of Searching Voluminous Materials}

Despite the repeated arguments that the advent of discovery of computerized materials increases the burden of responding to discovery, it could more often reduce that burden. The discovery battles of the last quarter century have largely emphasized the burdens imposed on responding parties, particularly due to document discovery. Many argued that these burdens were not warranted by any useful output. The proportionality principle was an effort to address that concern directly.

The proponents of restricting hard copy discovery have spoken in dire terms of the costs of responding to traditional document discovery, although some

42. James J. Marcellino \& Anthody A. Bongiorno, E-Mail Is the Hottest Topic in Discovery Disputes, NAT'L. L.J., Nov. 3, 1997, at B10.

43. For a list of articles about this subject, see Shira A. Scheindlin \& Jeffrey Rabkin, Electronic Discovery in Federal Civil Litigation: Is Rule 34 Up to the Task?, 41 B.C. L. REV. 327,341 n.53 (2000).

44. See generally Alan M. Gahtan, EleCtronic EvidenCe (1999); MiChael R. OVERLY. OVERLY ON ELECTRONIC EVIDENCE IN CALIFORNIA (1999).

45. See, e.g., Richard l. Marcus et al., Civil Procedure: A Modern Approach 345-46 (3d ed. 2000); Richard L. MARCuS \& EdWARD F. SHERMAN, Complex LiTIGATION: CASES AND MATERIALS ON ADVANCED CIVIL PROCEDURE 536-38 (3d ed. 1998).

46. See, e.g., Glasser Legal Works, Third Annual Conference on Electronic Discovery (Mar. 24, 2000).

47. See Steve Lohr, Antitrust Case is Highlighting Role of E-mail, N.Y. TIMES, Nov. 2, 1998, at C1 (describing the case as "the first major E-mail trial"). One who dies by the sword can also live by the sword; Microsoft itself profited by using e-mail evidence in another case. See Karen Donovan, E-Mails Helped Microsoft in Conn., NAT'L. L.J., Aug. 2, 1999, at A1 (describing how Microsoft used "damning e-mails" obtained from the plaintiff to good effect in the trial).

48. See, e.g., GAHTAN, supra note 44 , at $1 \mathrm{n} .2$ (asserting that discovery requests received by DuPont that explicitly referred to electronic evidence or e-mail increased from $2 \%$ to $30 \%$ between 1994 and 1999).

49. Scheindlin \& Rabkin, supra note 43 , at 361 . 
empirical information calls these arguments into question..$^{50}$ Those who would argue on cost grounds that the discovery of computerized material calls for a new rule regime must keep in mind that the case has already been made repeatedly that conventional discovery imposes huge costs. Therefore, the costs of the new technology might justify new rulemaking only if they were larger by an order of magnitude.

There is at least a theoretical ground for questioning whether this sort of increased cost has occurred or will occur. The Supreme Court noted more than twenty years ago that, ordinarily, the reason for using computerized information is to reduce costs. ${ }^{51}$ Word searches can make it much easier to locate pertinent documents in electronically stored materials compared to a search of similar hard copy records by hand. Reflecting that view, Judge Schwarzer has suggested that some discovery that would have been unduly costly under the proportionality principle before computers were developed would be permissible using the new technology. ${ }^{52}$

If responding parties always had to perform the old-fashioned document-bydocument review as well as an electronic search, the advent of new technology would not reduce their response burden, but it might not notably increase it either. Some report, however, that savings have not been realized, and the burdens have multiplied. ${ }^{53}$ Nevertheless, the existing rules already provide an argument for shifting away from the conventional page-by-page review of hard copy if computer searches can do an adequate job at a fraction of the cost. Since 1983, Rule 26 has directed judges to limit discovery by a litigant's preferred means if "the discovery sought ... is obtainable from some other source that is more convenient, less burdensome, or less expensive." ${ }^{54}$ Perhaps the ad-

50. See Thomas E. Willging et al., An Empirical Study of Discovery and Disclosure Practice Under the 1993 Federal Rule Amendments, 39 B.C. L. REV. 525, 577 tbl.28 (1998) (showing that, in general, deposition discovery costs more than twice as much as document discovery).

51. See Oppenheimer Fund, Inc. v. Sanders, 437 U.S. 340, 362 (1978) (addressing the use of computerized information to identify members of a class in a class action).

[A]lthough it may be expensive to retrieve information stored in computers when no program yet exists for the particular job, there is no reason to think that the same information could be extracted any less expensively if the records were kept in less modern forms. Indeed, one might expect the reverse to be true, for otherwise computers would not have gained such Id. widespread use in the storing and handling of information.

52. The judge explains:

Discovery that otherwise might be impermissibly burdensome, such as requiring detailed identification of all known documents referring to relevant issues, may not be burdensome if the computerized system is able to generate the identifications. Similarly, the existence of a computerized litigation support system will affect a party's obligation to identify business records produced in lieu of answering interrogatories.

William W Schwarzer et al., Civil Discovery and MaNdatory Disclosure: A Guide TO EFFECTIVE PRACTICE 1-23 (2d ed. 1994).

53. One of the participants in the April 15, 2000 Conference on Complex Litigation, a very experienced litigator, argued that using electronic means will never save effort because it will always be necessary to do just as much hard-copy review as before. He estimated that the advent of discovery of electronic materials had increased discovery retrieval burdens fourfold.

54. FED. R. CIV. P. 26(b)(2)(i). 
vent of computers has created an important role for this previously underused provision.

Some recent developments suggest that locating e-mail and similar electronically stored materials may not always be cripplingly difficult. ${ }^{55} \mathrm{We}$ are told that plaintiff attorneys in the Fen-Phen litigation used computer programs to locate documents helpful to their side, such that "unearthing corporate dirt came down in some instances to a few keystrokes." Em have begun to install "electronic sniffers" to identify e-mail communications that may violate their e-mail policies. ${ }^{57}$ Some employers have even started to install additional hard disks that make a copy of every keystroke, even those not saved to disk, much less transmitted to others, to monitor employee activities. ${ }^{58}$ Confronted with suits on behalf of disciplined or discharged employees, employers may be the first to use e-mails as evidence, saying in effect: "Here's why we fired the plaintiff." There may, however, be some legal limits on such control by employers. The National Labor Relations Board has taken an interest in the right of employees to use e-mail where the employer is unionized. ${ }^{59}$ One might also raise questions about such employer activities on privacy grounds. Overall, these reports suggest that it is not always difficult to locate similar materials in archived data when the other side desires them for use in a case. Electronic surveillance, however, is probably easier than retrospectively dredging huge amounts of archived electronic data, particularly if it was stored in a way that is difficult to search electronically. On balance, perhaps we have "an unprecedented opportunity to harness technology so as to prevent a rise in the delays and costs of discovery under Rule $34 .{ }^{, 60}$

55. Some legal service providers offer e-mail searching capacity. See, e.g., Ex-Litigator Founds Oakland Legal Services Firm, S.F. DAILY J., May 22, 2000, at 2 (describing the firm's "customized program, which enables it to enter a company's intranet and find 'the smoking-gun e-mail' that may decide a case").

56. Richard B. Schmitt, The Cybersuit: How Computers Aided Lawyers in Diet-Pill Case, WALL ST. J., Oct. 11, 1999, at B1.

57. See, e.g., Ann Carrns, Those Bawdy E-Mails Were Good for a Laugh-Until the Ax Fell, WALL. ST. J., Feb. 4, 2000, at A1 (describing the discharge of $10 \%$ of the New York Times Co. business office staff in Norfolk, Va., due to improper e-mail use that the company had detected); Lisa Guernsey, You've Got Inappropriate Mail, N.Y. TIMES, Apr. 5, 2000, at C1 (reporting that over 38\% of employers in 2000 review employees' e-mail messages, up from $14.9 \%$ in 1997). One reason for the growth in surveillance activity is that it has become easier. It is reported, for instance, that during the first half of 2000, "software has become more advanced, enabling companies automatically to record, filter and sort every word that streams through their networks." Guernsey, supra, at C1. As a result, one provider of this service said that "[t]he market for e-mail monitoring has basically doubled in size over the last year, and we anticipate it to grow very rapidly." Id. at C1. One need not be happy about this development, however. Judge James Rosenbaum has recoiled at the tale of spying on employees of the Times, for example, and urged that such employer scrutiny be constrained. See James M. Rosenbaum, In Defense of the Hard Drive, 4 GREEN BAG 2D 169 (2001). For further discussion, see infra text accompanying notes 88-93.

58. See Michael J. McCarthy, You Assumed "Erase" Wiped Out That Rant Against the Boss? Nope, WALL ST. J., Mar. 7, 2000, at A1 (describing new programs that "give employers access to workers' unvarnished thoughts").

59. See Micahel J. McCarthy, Sympathetic Ear: Your Manager's Policy on Employees' E-Mail May Have a Weak Spot, WAll ST. J., Apr. 25, 2000, at A1.

60. Scheindlin \& Rabkin, supra note 43, at 368. 
A more textured view may show that retrieving some older computerized materials - called "legacy data"-is qualitatively different from, and more difficult than, reviewing hard copy materials. The legacy data problem may afflict many discovery efforts, for discovery does not usually look to present or future, but to past events, which are less susceptible to the surveillance techniques mentioned above. This problem largely results from the pace of change in software and, to some extent, in hardware as well. Because electronic data may exist for a long time while the techniques of accessing the data may become technologically passe, a party who "possesses" older data may find it hard or impossible to access the information. Before computerized storage of data, the closest challenge to this problem was handling materials in another language; the cost of translation has caused disputes in the past. ${ }^{61}$ But the frequency and difficulty of the legacy data problem may be much greater unless a Rosetta Stone for accessing it becomes available. Otherwise, the proportionality principle might legitimately excuse heroic efforts to unearth the buried electronic data absent some articulable basis for believing that these measures are warranted.

\section{B. Electronically Stored Materials Contain Information That Is Not Always Included in Hard Copy Documents}

The starting point for the discovery of electronic data is to uncover the kinds of things that discovery has sought since the Federal Rules took effect. Hard copy discovery usually discloses only that which the creator decided to put on the page. One might request copies of all nonidentical copies to obtain earlier drafts and to see any notations put on copies of the final document by others. In each instance, however, the material was there because somebody wanted it to be put down on paper.

Electronically stored data conventionally include other information as well. A computer will automatically add details that it finds useful-such as the date on which a document was last modified and perhaps the identity of the person who made the modifications - that would not appear on the hard copy. Therefore, discovery of the electronic version might often be better than discovery of the hard copy, because it permits access to information that the creator of the document did not choose to create. This point is even more apparent with regard to records of Internet use and other insights that can be gleaned from examination of the hard disk of a personal computer. Many hard disks include files that detail Internet activity by the user of the computer, and various Internet sites may leave "cookies" on the hard disk whenever contact with the site occurs.

Obviously, this sort of material could be very important evidence in some cases. Those who wish to show that a document was falsified or altered may benefit greatly from an examination of the embedded data on the electronic

61. See id. at $356 \mathrm{n} .115$. 
version of the document. To show that a workplace exhibits a harassing atmosphere, an employee may rely on evidence of repeated visits to Internet sites with pornographic content. An employer wanting to show that an employee wasted time rather than doing her job may offer evidence detailing the employee's Internet visits to unrelated sites.

One could arguably treat this involuntarily created information as beyond the scope of the present definition of "documents" discoverable under Rule $34 .^{62}$ If so, a change in the rules might be needed to make this discovery available. One could then debate whether it is appropriate to do so. As an initial matter, it would seem that these electronic "fingerprints" should be no more immune to discovery than any other material that might be useful in making accurate determinations. Moreover, although the creator of the document may not have consciously intended to add these items to the document she created, it is clear that the creator of the software (and, in a sense, the purchaser of the software) did.

\section{Electronic Data May Contain Unguarded or Spontaneous Comments That} Are More Revealing than Hard Copy Data

The previous point dealt with information unintentionally included in a document and not evident on a hard copy. The fact that one can sometimes reconstruct a history of the changes to a document from electronic materials where that would not be possible with hard copy data shows how electronic data may be more complete.

The recent focus on discovery of e-mail communication goes beyond that point. It is now commonplace to recognize that people often make unguarded remarks in e-mail communications. "Employees say things in e-mail messages that would never be stated directly to a person or consciously memorialized in writing." ${ }^{63}$ To some, this characteristic shows that computer files constitute a "treasure trove of information for the computer-literate advocate." These unguarded comments may become even more important with the increasing use of laptop computers. ${ }^{65}$

At some point, one can ask whether this trove really contains treasure, or at least whether the evidence is worth the effort required to obtain it. Even the evidence rules recognize that what an employee says about her employer's activities is not automatically admissible against the employer over a hearsay ob-

62. See id. at 351 (suggesting that this "embedded"data might not be viewed as within the scope of discovery under Rule 34, but recognizing that courts usually find such data subject to discovery). For further discussion, see infra note 110.

63. James H.A. Pooley \& David M. Shaw, The Emerging Law of Computer Networks, Finding What's Out There: Technical and Legal Aspects of Discovery, 4 TEX. INTELL. PROP. L.J. 57, 63 (1995).

64. Anthony Tarricone, Discovery and Spoliation of Electronic Evidence, TRIAL, Dec., 1999, at 57.

65. See, e.g., Gregory Johnson, A Practitioner's Overview of Digital Discovery, 33 GONZ. L. REV. 347,370 (1997-1998) ("People tend to put more interesting things on a laptop than they would on a company desktop computer."). 
jection. ${ }^{66}$ But Federal Rule of Evidence 801(d)(2)(D) is rather generous, and will not often exempt offhand comments that an employee made about topics of which she actually knew little. Courts may also legitimately doubt that gathering comments equivalent to water cooler banter of bystander employees, even though "reasonably calculated to lead to the discovery of admissible evidence, ${ }^{, 67}$ warrants the effort involved, if that effort is considerable. ${ }^{68}$ At the same time, even "stray remarks" might be important in some cases, ${ }^{69}$ and access to the e-mail communications of the principal actors in the suit could indeed furnish a genuine treasure trove of important commentary.

Given the potential need to do an enormous search to locate a random remark by some employee that the party opposing the employer would like to use at trial (discussed further under the next two headings), e-mail may bring the basic proportionality principle front and center. But that principle already exists in the Rules.

\section{Electronic Data May Be More Durable and Harder to Discard}

Hard copy materials must be stored, take up space, and may become soiled or yellow over time. Sometimes they get lost. Electronic materials may endure almost forever unless overwritten, altered on purpose, or subjected to an errant magnetic field, and they take up very little space. Who among us does not have ancient floppy disks secreted away in some forgotten drawer? Moreover, the "delete" function on a PC does not actually do what it says; the hard drive of every computer still has on it electronic materials that the user considers long gone. ${ }^{70}$ Hard drives of computers no longer in regular use are likely to be chock

66. See FED. R. EvID. 801(d)(2)(D) (treating as "not hearsay" and hence admissible over a hearsay objection only those comments by an employee that relate to matters "within the scope" of the employee's job in an action against an employer).

67. FED. R. CIV. P. 26(b)(1).

68. For example, consider the views of one district judge who has studied problems of electronic discovery:

Today, legal discovery deep-sea fishes for snippets of deleted e-mails and deleted files in search of proof of imperfections. And the fish which are caught are thrown, as proof, into courtrooms throughout the land. In my view they are just fish, and as valueless as the same fish might be if allowed to rot as long as the finally-recovered file has been deleted. James M. Rosenbaum, In Defense of the Delete Key, 3 GREEN BAG 2D 393, 394 (2000).

Courts will need to be sensitive to the ways in which e-mails may be important, however. For instance, it is reported that, with the downturn in some tech stocks, claims have multiplied from new employees of high-tech firms who assert that they were not fully advised about the financial condition of the company. According to plaintiffs' lawyers, companies often respond that the new employees were fully familiar with the financial statements of the companies. However, "[o]ne Achilles heel is e-mail, which can show a very different side of how a company portrays itself." Meredith Alexander, Promises, Promises, Internet Companies Accused of Fraudulent Inducements, CALIF. LAWYER, Aug. 2000 , at 20.

69. See Spencer v. Stuart Hall Co., 173 F.3d 1124 (8th Cir. 1999) (holding that the district court did not abuse its discretion by admitting "stray remarks" of former employees in an age discrimination action, but premising the ruling in large measure on the defense's grilling of the plaintiff about his grounds for thinking that his discharge was caused by his age).

70. The delete key merely tells the computer it may use the disk space for another purpose; it does not actually erase anything. The material remains on the disk until overwritten. "It is now clear that relatively simple devices can recover almost everything that has been 'deleted."' Rosenbaum, supra note 68 , at 393 . 
full of old data of this sort. Even overwritten areas of a hard drive may contain data that can be resurrected with forensic efforts. ${ }^{71}$

Some aspects of computerized material are distinctive because they make available items that would previously have been lost. In assessing these developments, however, one must keep in mind the impact of other technological developments since 1938, for they also meant that much more material could be found than was true in the world of the original drafters of the Federal Rules. The photocopy machine did not exist in 1938, and the volume of paper created grew enormously when photocopies became ubiquitous. That, indeed, is one of the reasons why computerized information storage is preferable-hard copies take up too much space. Moreover, it was said twenty years ago that one should always assume that any document has been copied at least ten or twenty times, and that those marked "confidential" had been copied at least fifty times. In the same vein, before computers came along, some documentary pack rats kept drafts as well as the final document, and these drafts could be located with enough effort. On second thought, then, the break with the past does not seem to be so striking.

Perhaps, however, the likelihood of effectively discarding hard copies makes computerized materials different. Putting aside shredding machines, there have been cases in which people who sought to throw away hard-copy documents found that the documents surfaced anyway. ${ }^{12}$ Those stories are eye-catching because they are unusual; in fact, almost all hard copies that are "deleted" by being thrown into the waste basket are soon gone forever. It is possible that there is some way to introduce this reality into the discovery of electronic materials, such as treating any "deleted" document as nonexistent for purposes of the initial search burden, but that might be dubious-unless tied to proportionality or coupled with the notion that "deleted" materials are not very probative anyway.

A particularly significant application of this general principle relates to interim drafts of documents whose final versions are important in litigation. Given the myriad places in which electronic material can be found, one could probably unearth many interim versions if enough effort were made to find them. Sometimes that effort may be justified, but consider that a lawyer will often rewrite ordinary letters three or four times before sending them. All those drafts might be found somewhere. But it is hardly obvious that, as a general rule, insisting on heroic efforts to disinter interim versions would make sense.

71. See id.

72. See, e.g., McCafferty's v. Bank of Glen Burnie, 179 F.R.D. 163 (D. Md. 1998) (involving a third party who retrieved from a dumpster a document that had been torn into pieces); Suburban Sew ' $N$ Sweep, Inc. v. Swiss-Bernina, Inc., 91 F.R.D. 254 (N.D. Ill. 1981) (involving a plaintiff who removed privileged materials from the defendant's garbage). 


\section{E. Searches for Electronic Materials May Require Looking in Many Additional Locations}

One distinctive feature of electronic material is portability. A floppy disk can easily be carried home or on a trip, but contains hundreds of pages' worth of material. An e-mail message may circle the globe in an instant, leaving a copy on many servers. A computer user may leave messages or electronic footprints at Internet sites on every continent. Backup tapes are often created daily or weekly to store everything on a company's system and then stored off site. Even places where nobody intended to store information may contain it. If heroic efforts are warranted, some even suggest examining of the UNDO file in WordPerfect, which may store some 250 document alterations, ${ }^{73}$ as well as printers and fax machines that have a memory capacity capable of storing electronic data that would fill several hundred pages of hard copy. ${ }^{74}$

When it comes time to locate all these materials, the dimensions of the search may look daunting and unprecedented. The pertinent comparison, however, is to a customary search for hard copies. In theory, that could mean that a large organization must open every drawer in every desk worldwide. That is not usually done, however, because some lesser and more focused effort is undertaken. Perhaps a similar focus could be achieved with electronically stored materials. As noted above, the possibility of electronic searching could theoretically reduce rather than increase the effort involved. This difference is not necessarily qualitative. The difference may not even be quantitative with electronic materials, particularly if hard copy searching could be curtailed in favor of computerized searching of electronic databases. ${ }^{75}$

\section{F. Spoliation and Preservation Problems May Multiply}

The "embedded data" possibility mentioned above suggests that spoliation will not be a serious concern because often it may be possible to determine when changes to a document have been made and who made them.

At the same time, however, there are heightened concerns about the alteration and the destruction of electronic information. On the one hand, the risks of phony evidence may multiply. E-mail, for instance, may sometimes be faked or diverted. ${ }^{76}$ Embedded data itself might be altered on purpose. But on the other hand, the durability of this material gives rise to remarkable preservation

73. See Johnson, supra note 65 , at 360 .

74. See OVERLY, supra note 44 , at 2-24 to 2-27.

75. Some argue that this will not happen. See supra note 53 .

76. See Scheindlin \& Rabkin, supra note 43, at 339 ("It is fairly easy for knowledgeable computer users to create e-mail messages that falsify this [source] information."). In California, for example, a disgruntled former employee used a fake e-mail message allegedly from her boss as evidence in her suit against the company. She was later convicted of perjury and falsifying documents for doing so. See Carol Marie Cropper, Earning It: The Unwritten Code Against Fraternization, N.Y. TIMES., Oct. 26, $1997, \S 3$, at 14 . Others use deliberately confusing email addresses to lure people into sending messages to them. See Michael Moss, Inside the Game of E-Mail Hijacking, WALL ST. J., Nov. 9, 1999, at B1 (describing techniques of luring people into sending e-mail messages to unintended recipients). 
difficulties. In part, this results from facts mentioned above-that the "delete" function does not actually destroy data, and that electronic data can exist almost forever unless overwritten. The alteration or destruction of that "deleted" data may, however, be unintended. Simply turning on a personal computer might destroy some such data, ${ }^{7}$ so one could insist that once litigation commences, or when the prospect appears on the horizon, no personal computer of a party or potential party should be turned on. That sort of overbroad preservation idea suggests the magnitude of the new spoliation concern.

In some ways, these problems are qualitatively different from the parallel issues that arise in connection with preservation of hard copy materials. It is less clear, however, whether they are quantitatively different, and that may be the more important comparison. The space required to store huge amounts of electronic data is not great, so requiring retention of electronic data may not be overly burdensome. Indeed, some say that saving storage space can never suffice to justify erasure of electronic material. ${ }^{78}$ It is also possible that document preservation functions are more centralized as well for much electronic material as compared to hard copies. For example, there may be a single computer program that has been directed to delete all e-mail or other materials of more than a certain age unless a computer user has specially stored the material. In these circumstances, it is probably much easier to stop the document erasure than it would be to stop a large number of people from throwing out hard copies. Therefore, in terms of the burden, it may be that the task of preservation is less onerous with some kinds of electronically stored materials than with hard copies. Nevertheless, with "deleted" but not overwritten data, stopping all use of a party's computers would obviously be a major intrusion on its operations. Also, given the volume of e-mail communication today, stopping the deletion of dated messages could produce such a volume of stored messages that it would cripple the system. Even the White House has had a problem with retaining and retrieving e-mail. ${ }^{79}$ Others will also have these problems.

77. See Pooley \& Shaw, supra note 63 , at 62 (" $[\mathrm{A}]$ company, by simply continuing to use its computers after the lawsuit has been filed without safeguarding the data present in its system, can destroy otherwise valuable evidence that should be available to the adversary.").

78. A prominent lawyer so asserted during an October 27, 2000 conference held by the Discovery Subcommittee of the Advisory Committee on Civil Rules at Brooklyn Law School.

79. A computer glitch reportedly resulted in the failure of the White House e-mail system to monitor certain incoming e-mail messages for material subpoenaed by Congress. See Marc Lacey, White House E-Mail Feud Grows, N.Y. TIMES, Mar. 20, 2000, at A17. Initial estimates said that it would cost $\$ 3$ million and take as long as three years to fix the problems. See id. Later the White House reported that it could not find backup records because no backup copies had been made. See David Johnston, White House Cannot Recover a Year of Messages, N.Y. TIMES, June 9, 2000, at A22; see also Don Van Natta, Ex-Clinton Counsel Grilled on E-Mail Issue, N.Y. TimEs, May 5, 2000, at A20 (reporting on questions regarding e-mails directed toward Charles Ruff by congressional committee); $c f$. Alexander v. F.B.I., 188 F.R.D. 111 (D.D.C. 1998) (holding that the plaintiffs were not entitled to discovery that would have required the Executive Office of the President to search through its system of e-mail and to engage in wholesale restoration of archived e-mail and deleted computer files). 


\section{G. On-site Inspection May Become Much More Important}

Since its beginning, Rule 34 has authorized a request to inspect the premises of a party ${ }^{80}$ and for a decade, Rule 45 has authorized a subpoena to do the same thing on the premises of a nonparty. ${ }^{81}$ But this is a rare occurrence, and may have been disfavored by courts. ${ }^{82}$ That may change; as one lawyer experienced with discovery of electronic materials forecasts, "[s]ometime or another, an onsite visit will be necessary." ${ }^{\prime 83}$ Indeed, an on-site inspection may be the only way to determine whether "deleted" but relevant materials exist, or to query the responding party's computer system to obtain important information. A measure of standardization may even be emerging. ${ }^{84}$

Because this previously unusual event may now become commonplace, the advent of discovery of computerized information could present qualitatively new problems. Beyond that, it raises new issues because the software needed to access or use the data so obtained may itself be subject to trade secret protection.

\section{H. Experts May Now Be Needed for Electronic Discovery}

"Digital discovery is not for neophytes." ${ }^{85}$ Many lawyers say that they need to hire outside experts to do this kind of discovery, and forensic computer specialists have rushed to fill this need, creating a new cottage industry. Indeed, the possibility that there has been an informal standardization for on-site inspection appears to be based on the assumption that the lawyer will hire such an expert unless there is one on staff. ${ }^{86}$ Making a mirror copy of a hard disk without turning on the computer is not something that most lawyers can do. In the same vein, courts themselves may need to employ an expert to supervise or perform an on-site inspection. ${ }^{87}$

But there are some analogies in past experience. Lawyers often hire experts to assist them in analyzing and challenging the testimony of their opponents' experts. Twenty years ago, litigation support systems were often provided by outside vendors, but today's computer advances and the growing sophistication

80. FED. R. CIV. P. 34.

81. Id. 45 .

82. See, e.g., Belcher v. Bassett Furniture Indus., 588 F.2d 904, 908 (4th Cir. 1978) ("Since entry upon a party's premises may entail greater burdens and risks than mere production of documents, a greater inquiry into the necessity for inspection would seem warranted.").

83. Johnson, supra note 65 , at 371.

84. Thus, commentators emphasize that the party seeking discovery should allow all computer manipulations to be undertaken by the responding party's personnel. Additionally, the party doing discovery should be very careful not to alter the responding party's system or data. See Johnson, supra note 65, at 372-73. For an example of the pitfalls, consider Gates Rubber Co. v. Bando Chemical Industries, 167 F.R.D. 90, 111-12 (D. Colo. 1996), in which the discovering party's expert loaded software onto the responding party's drives that overwrote the existing data.

85. Johnson, supra note 65 , at 359.

86. See supra text accompanying note 84.

87. See e.g., Playboy Ent., Inc. v. Welles, 60 F. Supp. 2d 1050, 1055 (S.D. Cal. 1999) (appointing computer expert to create a mirror image of the defendant's hard drive). 
of lawyers in using computers has brought this expertise in-house in many firms. Therefore, perhaps the reliance on outsiders is a short-term phenomenon, and the number of lawyer neophytes will diminish while the number of in-house experts at law firms will increase.

\section{Discovery Could Become Even More Intrusive}

George Orwell's 1984 defined the height of intrusion that the government could manage: Citizens were subjected to constant observation via monitors in their homes. ${ }^{88}$ To a considerable extent, computers now enable citizens to afford the world such surveillance of themselves through cyberspace. Some people have even set-up web pages that broadcast what a camera fixed in their homes depicts. ${ }^{89}$ Perhaps these people would have liked Orwell's Hell. Similarly, as noted above, employers can pervasively monitor what their employees say inside and outside of the workplace because so much of this communication is done via e-mail.

Intrusiveness has been an issue since broad discovery was first introduced. As a district court observed fifteen years ago, "[e]xcept for a few privileged matters, nothing is sacred in civil litigation." rials such as diaries turned over to litigation opponents." But perhaps the intrusiveness now possible is of a different magnitude, and calls for revising the basic idea that protecting privacy should be the exception, not the rule, where discovery is concerned. ${ }^{92}$

\section{J. Discovery Burdens Might Be Spread More Evenly}

A recurrent theme in objections to broad discovery has been the specter of "one-way discovery." Organizational litigants, usually in the defense posture,

88. GEORGE ORWELL, 1984 (Harcourt Brace Jovanovich 1977) (1949).

89. A recent article in the New York Times Magazine describes the founder of www.nerdman.com, which makes available continuous stream observation on the Internet from six cameras stationed in his home, as well as other cameras in his workplace. See Marshall Sella, The Electronic Fishbowl, N.Y. TimES, May 21, 2000, $\S 6$ (Magazine), at 50. It also describes a television show in the Netherlands that involved continuous surveillance of nine volunteers locked in a house together for 100 days, described as an "unscripted Orwellian drama" and called "Big Brother." The author adds:

On the Web, you can watch pedestrians shuffle through Times Square or Red Square, take in the morning bustle of a Parisian hotel lobby, spy on fruit bats at the Smithsonian or gawk at a burly man kneading dough at Mandee's Pizza in Beverly, Mass. You can stare out the exact window of Dealey Plaza from which Lee Harvey Oswald is believed to have shot J.F.K. Or you can sit, long after midnight, as I have, watching people read and eat toast. You can watch people watch TV.

Id. at 53 .

90. Coca-Cola Bottling Co. v. Coca-Cola Co., 107 F.R.D. 288, 290 (D. Del. 1985) (dealing with the discovery of the Coca-Cola formula).

91. See, e.g., Zises v. Department of Soc. Servs., 112 F.R.D. 223, 224 (E.D.N.Y. 1986) (requiring an employment discrimination plaintiff to turn over her journal, in which she wrote 20 to 30 pages daily that she described as a "stream of unconscious becoming conscious"); see also Senate Select Committee on Ethics v. Packwood, 845 F. Supp. 17 (D.D.C. 1994) (enforcing a subpoena for Senator Packwood's personal diaries in connection with allegations of sexual harassment).

92. For a judicial suggestion that there should be such a reorientation, albeit in connection with employer searches of employees' computers, see Rosenbaum, supra note 57. 
often claim that individual plaintiffs can make unlimited discovery demands without facing any real burden in responding because they have such limited information. Plaintiffs respond to this objection by arguing that defendants engage in "dump truck" tactics that deluge plaintiffs with voluminous, irrelevant material. Interestingly, the 1997 study of discovery practice by the Federal Judicial Center suggested that in high-discovery cases-the complex cases with which this symposium is concerned-discovery actually costs plaintiffs more than defendants.

At first blush, it would seem that the one-way discovery "advantage" individual plaintiffs possess may have increased in the Internet age because there are more places for the organizational litigant to look and more items to be dredged up by computer forensic experts. Certainly some say that the advantage is now greater. ${ }^{94}$ On second glance, however, the balance might be restored to some extent. The privacy concerns mentioned above are more likely to be important to the individual litigant than to the organizational one. Moreover, an increasing proportion of the American population has access to and uses a computer at home. Consider the variety of items of information, embedded and otherwise, that might exist on that computer.

"Computers... enable individuals and small businesses to store immense quantities of data-thus exposing them to the risk of litigation costs totally out of proportion to their ability to bear those costs. ${ }^{.95}$ Indeed, one of the first reported cases in which there was an on-site inspection of a computer hard disk involved discovery by a large corporate plaintiff against a defendant who was a sole proprietor. ${ }^{96}$ And a leading example used to illustrate the possibly intrusive consequences of this sort of discovery involved discovery by a corporate plaintiff from the individual computers of its employees. ${ }^{97}$ One cannot say that the shoe is on the other foot, but instead that it may now be on both feet.

\section{K. Electronic Discovery and Related Developments Could Fundamentally Alter the Mode of Litigation}

On a more speculative level, one might see the introduction of the right to take videotaped depositions in the 1993 amendments as a harbinger of something that could arrive with the computer revolution-the virtual courtroom.

93. See Willging et al., supra note 50 , at 547 tbl. 3, 548 tbl. 4 (showing that, at the 95 th percentile of the cases in the survey, discovery cost plaintiffs one-third more than it cost defendants).

94. See, e.g., Cortese \& Wolfe, supra note 41 (reporting that the expanding use of electronic communications can "transform seemingly innocuous discovery requests into often Herculean and invasive exercises"). "Recognizing the unique burdens and costs involved, discovering parties often exploit existing limited technological knowledge in broad electronic discovery orders. As such, discovery of electronic evidence can be deployed as an offensive weapon to compile cost-of-litigation settlements." Id.

95. Scheindlin \& Rabkin, supra note 43, at 349.

96. See Playboy Ent., Inc. v. Welles, 60 F. Supp. 2d 1050, 1050 (S.D. Cal. 1999).

97. Northwest Airlines obtained a court order authorizing it to search computers used by employees to determine whether they had used the computers to foment a "sick-out" against the airline. For a discussion of this discovery, see http://cyber.law.harvard.edu/digitaldiscovery/digdisc_library_l.html (visited Jan. 31, 2001). 
At present, technology is the stepchild of conventional litigation; even the videotaped deposition is allowed in evidence only when the witness is not available. ${ }^{98}$ But with the advent of teleconferencing, one could adapt depositions to avoid costly travel, and perhaps to produce digital output that one could use to create a video trial product that would supersede the contemporary trial. ${ }^{99}$

These possibilities have not eluded notice. More than ten years ago, I explored developments that might be changing the American method of trial. ${ }^{100}$ Then, in 1998, Paul Carrington surveyed the possibilities for new modes of trial in the new millennium. ${ }^{101}$ At least some reports indicate that this "new millennium" is partly here. ${ }^{102}$

There are already precedents for the aggressive use of technology to alter the trial process. Over twenty years ago, state courts in Ohio used pre-recorded videotaped trials. ${ }^{103}$ More than a decade ago, a federal district court in Texas allowed videotaped depositions to be used at trial to create "a presentation that closely resembled a television documentary or news report." ${ }^{104}$ In 1999, a federal district court ordered a trial by video conferencing in a suit brought by a prisoner incarcerated at a great distance from the courtroom. ${ }^{105}$ Less aggres-

98. See FED. R. CIV. P. 32.

99. Already, some lawyers use videoconferencing to eliminate the cost of travel by some witnesses. Various office supply companies have reportedly established video conferencing rooms around the country that can be rented by the hour. See Samuel L. Davis, A Practical Guide to Videoconferencing, TrIAL, Mar. 2000, at 48; Hope Viner Samborn, Click Onto World Wide Web Deps, 86 A.B.A. J. 72 (2000). At least one judge has allowed use of such a facility in Israel to produce testimony for use in an American court. See Davis, supra, at 49.

100. See Richard Marcus, Completing Equity's Conquest? Reflections on the Future of Trial Under the Federal Rules of Civil Procedure, 50 U. PITT. L. REV. 725 (1989) (examining the question whether the Anglo-American commitment to the in-court, in-person trial was warranted).

101. See Paul D. Carrington, Virtual Civil Litigation: A Visit to John Bunyan's Celestial City, 98 COLUM. L. REV. 1516 (1998) (exploring the potential impact of the development of the computer on civil litigation).

102. See, e.g., Schmitt, supra note 56, at B1 (describing the use of technology by the plaintiffs' counsel to assemble and use evidence, including e-mails).

103. See James L. McCrystal \& Ann B. Maschari, Will Electronic Technology Take the Witness Stand?, 11 U. TOL. L. REV. 239 (1980) (describing Ohio practice).

104. C. Michael Buxton \& Michael Glover, Managing a Big Case Down to Size, 15 LITIG. 22, 22 (1989). For a description of the trial by the trial judge, see Robert M. Parker, Streamlining Complex Cases, 10 REV. LITIG. 547 (1991).

105. See Edwards v. Keen Mountain Correctional Officer Logan, 38 F. Supp. 2d 463 (W.D. Va. 1999). The court thought that the $\$ 8,000$ cost of transporting the plaintiff would be too high. It noted that the plaintiff "will be virtually present at his trial and will have the ability to confront witnesses, ... and participate fully." Id. at 467-68. Although the judge recognized that "it is to be expected that the ability to observe demeanor, central to the fact-finding process, may be lessened in a particular case by video conferencing," he thought that this concern was not great because the case was "relatively simple and straightforward." Id. at 467.

For another illustration of judicial receptivity to virtual participation in a trial, see F.T.C v. Swedish Match N. Am., Inc., 197 F.R.D. 1 (D.D.C. 2000), in which the court allowed plaintiff to present the testimony of a witness who resided in Oklahoma via live video testimony. Defendants objected that this technique violated Fed. R. Civ. P. 43(a), but the court disagreed. The judge explained that "I can say that there is no practical difference between live testimony and contemporaneous video transmission based upon my experience presiding over two hearings." Id. at 2 . He recognized that "the Committee Notes to Rule 43(a), upon which the defendants rely, are more hostile to live video transmission." But 
sively, one could promote the use of electronic versions and electronic storage of data. Web-based document depositories, for example, might produce significant savings in multi-party cases.

If we move in this direction, we would surely travel into uncharted waters, but the contrast between the use of technology in trial and in discovery is a fitting one for evaluating whether the advent of electronic discovery truly brings us into uncharted waters also. Frankly, the prospective change to the mode of trial sounds revolutionary, but the prospects regarding discovery are much less so.

\section{IV}

\section{POSSIBLE REACTIONS}

If the discovery issues are new and different, they may call for new and different procedures. Those might be achieved by at least three routes: (1) amending the rules; (2) relying on a manual; and (3) judicial education.

\section{A. Amending The Rules}

When the question arose as to whether the Federal Rules of Evidence should be amended to address problems generated by the use of computerized materials as evidence, the conclusion was that no amendments were warranted. ${ }^{106}$ Perhaps the same reaction is appropriate for the Federal Rules of Civil Procedure. As an initial matter, even though computers are the champions at counting things, it seems that the quantitative method of limiting discovery that was adopted for interrogatories and depositions would not serve a purpose, and that the only recent theme for discovery reform that holds some promise is based on proportionality.

The question of whether to propose amendments is at least worth addressing in a concrete way, and this section outlines some places in which the Civil Rules might be amended to respond to the developments discussed here. It is important to emphasize, however, that as of this writing these ideas are just that-ideas of a nonmember of the Advisory Committee on Civil Rules. That Committee has not taken action or, as of this writing, even discussed whether any particular rule should be amended or whether a possible amendment to any rule should be developed.

the courts do not reflect that hostility any more; "the courts are much more receptive to this new technology than the Advisory Committee." Id. at 5-6.

106. See Memorandum from Don Capra, Reporter, to the Advisory Committee on Evidence Rules (Mar. 1, 1998) (on file with author) (discussing 29 evidence rules that might be amended). By and large, the changes responded to concerns that the wording of the current rules might not adequately describe the electronic reality. For example, there are repeated references in the Federal Rules of Evidence to a "writing," and that might not be taken to include computer-based information. But the Reporter could find no indication that the courts were having a problem due to these issues, and he did express concern that changing so many rules might confuse matters. After a discussion, the committee decided not to take any action. See Minutes, Advisory Committee on Evidence Rules 9 (Apr. 6-7, 1998). 
Against that background, this article offers some ideas that emerge from a preliminary evaluation of the current rules.

- Rule 26(a)(1). The initial disclosure process might be adapted to require some early exchange of concrete and detailed information about parties' storage of electronic data.

- Rule 26(a)(2). The disclosures about expert testimony might be revised to require more extensive disclosure of any use of electronic data by an expert in connection with forming opinions to be expressed at trial.

- Rule 26(a)(3). The pretrial disclosures could be expanded to mandate early revelation of the intention to use computer-generated evidence at trial so that there would be time to investigate foundational questions. ${ }^{107}$

- Rule 26(b)(1). The rule now says that discovery is authorized about "the existence, description, nature, custody, condition, and location of any books, documents, or other tangible things." This language seems out of date and could be revised to include explicitly the electronic materials identified in Rules 26(a)(1) and 34(a).

- Rule 26(b)(1). The rule also could be revised to address specifically the question whether electronic data unintentionally created by the drafter of a document - such as "embedded data" and "cookies"should be considered within the scope of discovery. ${ }^{108}$

- Rule 26(b)(5). This rule regarding claims of privilege might be modified to take account of the special problems of identifying privileged items that can arise in connection with voluminous, electronically stored materials.

107. For an example of a rule dealing with these matters, consider Maryland Rule of Civil Procedure 2-504.3(b), which requires a party who intends to use such evidence at trial to provide written notice of that intention $\mathbf{9 0}$ days before trial. Thereafter, there is an opportunity to probe the admissibility of the evidence through discovery, and objections must be made before trial. Arguably, it is preferable to move up the time for the revelation of the existence of such evidence to the point when Federal Rule of Civil Procedure 26(a)(2) disclosures are required, so that investigation of foundational matters accompanies the rest of discovery. This is particularly appropriate given the likelihood that much of the evidence would likely require the sponsorship of an expert witness. But the cost of preparing such evidence at that stage in the litigation, and the possibility that it would need to be modified before trial, militate against including such a provision in Federal Rule of Civil Procedure 26(a)(2).

108. The American Bar Association Civil Discovery Standards allow a party to request "the production of ancillary electronic information that relates to relevant electronic documents, such as information that would indicate (a) whether and when electronic mail was sent or opened by its recipient(s) or (b) whether and when information was created and/or edited." CIVIL DISCOVERY STANDARDS 29 b.i. (1999) [hereinafter ABA STANDARDS]. 
- Rule 26(c). The protective order rule might be revised to take explicit account of proprietary information, privacy, and other issues raised by this form of discovery.

- Rule 26(d). This rule imposes a discovery moratorium pending the Rule 26(f) conference. It might be the place to provide rules about spoliation or preservation of electronic materials, if such issues were susceptible to treatment in a rule.

- Rule 26(f). This rule could be amended to address planning for the discovery of electronic materials explicitly, and Form 35 might also be modified to raise the profile of such materials. ${ }^{109}$ In particular, there might be provisions inviting the development of a protocol to deal with issues of preservation and spoliation.

- Rule 26(g). The signature requirement might be modified for situations where discovery is served or responded to in electronic form.

- Rule 30(b)(2) and (3). As electronic media become more important in depositions, one might ask whether the current authorization for alternative methods of recordation, added only in 1993, might be expanded or revised to take account of new methods.

- Rule 30(b)(5). The authorization for a deposition notice to require the witness to bring along "documents and tangible things" might be modified to include material stored electronically, although the invocation of Rule 34 probably does the job to the extent Rule 34 does the job.

- Rule 30(b)(6). One might develop a special procedure in the rules for depositions of people such as information systems managers to provide useful and inexpensive information about how the systems work. The rule might direct that this inquiry occur during a "first wave" of discovery activity.

- Rule 30(b)(7). This rule now allows the parties to stipulate, and the court to order, that a deposition "be taken by telephone or other remote electronic means." As the technology of video conferencing improves, perhaps the rules could more actively promote the use of that technique. relevant issues, such as the search for, location, retrieval, form of production and inspection, preservation, and use at trial of information stored in mainframe or personal computers or accessible "online." MANUAL FOR COMPLEX LITIGATION, supra note $36, \$ 21.446$ 
- Rule 32(a)(3). At present, this rule permits the use of depositions, including videotaped depositions, at trial only when the witness is unavailable, except in "exceptional circumstances." This could be changed if there were a desire to facilitate the presentation of videotaped evidence at trial.

- Rule 33(a) and (b). These rules might be changed to direct, or authorize parties to insist upon, the service of questions and answers in electronic form. The signing requirements would have to be revised accordingly.

- Rule 33(d). The option to produce business records might be revised in some way to take account of the special problems involved in producing records that are in electronic form, or the methods by which the access to such records is to be given.

- Rule 33 or 34 . Either here, or elsewhere, the rules might set forth the criteria for permitting a party to insist on the ability to request access to another party's electronic information and the ground rules for such access.

- Rule 34(a). The description of electronic materials might be modified. The current description was written in 1970, when much less was known about computers. It might be desirable to specify what sorts of things fall within the term "data compilations" to make clear that e-mails are included. ${ }^{110}$

110. ABA Standards 29 a.ii. states that "[u]nless otherwise stated in a request, a request for 'documents' should be construed as also asking for information contained or stored in an electronic medium or format." ABA STANDARDS, supra note 108, at 29 a.ii. On the other hand, in Texas, "the requesting party must specifically request production of electronic or magnetic data and specify the form in which the requesting party wants it produced." TEX R. CIV. P. 196.4. Thus, the presumption could go either way.

Recently, Judge Scheindlin has summarized the situation as follows:

Courts and commentators have generally interpreted Rule 34 and its accompanying Advisory Committee Note to allow the discovery of electronic evidence. As Magistrate Judge Andrew Peck concluded in an oft-quoted phrase several years ago, "today it is black letter law that computerized data is discoverable if relevant." And, one leading treatise on federal civil procedure states that "[ $\mathrm{t}$ ]he rule now clearly allows discovery of information even though the information is on computer." The absence of any recent decisional law or commentary taking a contrary position illustrates that if there were doubts as to whether Rule 34 permitted discovery of electronic documents such as e-mail when it was amended in 1970, those doubts now have been universally dispelled. As stated earlier, however, whether the Rules permit discovery of the newest forms of electronic evidence such as cookies, temporary files and residual data remains an open question.

Scheindlin \& Rabkin, supra note 43 , at 350-51. 
- Rule 34(a). The rule might alternatively be changed to eliminate the duty to search electronic media unless specifically requested."'

- Rule 34(a). Provisions relating to the preservation of electronic materials could be inserted and possibly linked to making document requests for these materials.

- Rule 34(a). One could insert a provision on whether, or when, nonidentical electronic copies must be produced.

- Rule 34(a). If an appropriate protocol or set of prerequisites for on-site inspection of computerized materials could be developed, it could be inserted here as a further specification of the circumstances when one may inspect a designated property. ${ }^{112}$ This might be coordinated with rule treatment of use of an expert or a special master. ${ }^{113}$

- Rule 34(b). The rule could be amended to provide that there is no obligation, absent a court order, to search materials that have been electronically deleted by the creator or recipient.

- Rule 34(b). If there are specialized problems relating to the production of materials in electronic format, they might be addressed by special rule provisions. ${ }^{114}$ The provision added in 1980 requiring that documents be produced either as they are kept in the usual course of business or to correspond with the categories in the re-

111. In Texas state courts, such a provision now exists: "To obtain discovery of data or information that exists in electronic or magnetic form, the requesting party must specifically request production of electronic or magnetic data and specify the form in which the requesting party wants it produced." TEX. R. CIV. P. 196.4. This provision also has specific directives on the form of production and the allocation of costs. See infra note 114.

112. On this point, consider Strasser v. Yalamanchi, 669 So. 2d 1142 (Fla. Ct. App. 1996), in which the court said that the plaintiff could search defendant's computer for purged information only if the plaintiff showed that retrieving the information was likely, and that there was no less intrusive way to obtain it.

113. Note that the ABA Standards suggest that "[i]n complex cases and/or ones involving large volumes of electronic information, the court may want to consider using an expert to aid or advise the court on technology issues." ABA STANDARDS, supra note 108, at 29 b.ii.

114. The ABA Standards state that "[a] party may ask for the production of electronic information in hard copy, in electronic form or in both forms." Id. at 29 b.i.

Texas now has provisions specifically referring to both the form of production and the allocation of the cost:

The responding party must produce the electronic or magnetic data that is responsive to the request and is reasonably available to the responding party in its ordinary course of business. If the responding party cannot-through reasonable efforts-retrieve the data or information requested or produce it in the form requested, the responding party must state an objection complying with these rules. If the court orders the responding party to comply with the request, the court must also order that the requesting party pay the reasonable expenses of any extraordinary steps required to retrieve and produce the information.

TEX R. CIV. P. 196.4. 
quest (the last paragraph of this subdivision) might be the place to focus in developing this set of provisions.

- Rule 34(b). A provision might also be added explicitly giving the court authority to authorize a "quick peek" at an opponent's documents without causing a privilege waiver. ${ }^{115}$

- Rule 34(b). The rule could be amended to clarify that the responding party need not produce electronically stored information in hard copy format if it chooses to use an electronic format (providing the other side can access it in that format), or to condition such hard copy production on the payment of the resulting costs. ${ }^{116}$

- Rule 37. Some specialized rules about spoliation of electronic materials might be added here.

115. In Playboy Entertainment, Inc. v. Welles, 60 F. Supp. 2d 1050 (S.D. Cal. 1999), the court not only appointed a special master to review defendant's hard disk, it also provided as follows:

To the extent the computer specialist has direct or indirect access to information protected by the attorney-client privilege, such "disclosure" will not result in a waiver of the attorney-client privilege. Plaintiff herein, by requesting this discovery, is barred from asserting in this litigation that any such disclosure to the Court designated expert constitutes any waiver by Defendant of any attorney-client privilege.

Id. at 1055 (emphasis added).

116. Since 1980, Rule 34(b) has directed that "[a] party who produces documents for inspection shall produce them as they are kept in the usual course of business or shall organize and label them to correspond with the categories in the request." FED. R. CIV. P. 34(b). This provision seemingly should give the choice to the producing party to select the manner of production, although some argue that the discovering party can insist on production in a certain format. Certainly this rule provision was addressed to a different issue, and sought to constrict the options available to a responding party in a different way:

To begin with, the problem addressed in the 1980 amendment was the shifting of materials from the sequence in which they were ordinarily kept to somewhere else, perhaps intended to make them hard to find. For instance, a critical internal memorandum might be taken from the memoranda file and buried among mounds of invoices. The amendment forbids the producing party from thus making it harder to find such items. Similarly, the producing party does have a burden to select and produce the items requested rather than simply dumping large quantities of unrequested material onto the discovering party along with the items actually sought under Rule 34. Requiring further that these requested materials be segregated according to the requests would impose a difficult and usually unnecessary additional burden on the producing party. The categories are devised by the propounding party and often overlap or are elastic, so that the producing party might be compelled to decide which best suits each item in order to consign it to the proper batch. Such an undertaking would usually not serve any substantial purpose, and it could become quite burdensome if considerable numbers of documents were involved. Moreover, by requiring rearrangement, and the disassembling of the producing party's files, insisting on this manner of production invites claims of the very sort of "hiding" of materials that gave rise to the 1980 amendment. Accordingly, in the first instance the producing party should retain the right to choose between the production formats authorized by Rule 34(b) (but not others), and the court should have the authority where necessary to direct some disclosure of the manner of organization of the producing party's files.

8A WRIGHT ET AL., supra note $25, \S 2213$, at 431-32. 
- Rule 37. Specific criteria could be added for resolving a motion to compel discovery of computerized information. ${ }^{17}$

\section{B. Relying on a Manual}

The Manual for Complex Litigation already has provisions dealing with the discovery of electronically stored material. ${ }^{118}$ One might argue that the changes suggested above as possible amendments to the Rules would be better included in a manual format. But a manual is just that-a set of ideas with no prescriptive force. Therefore, one who feels that certain solutions should be followed would likely not be satisfied with including them only in a manual.

\section{Judicial Education}

Some lawyers think that some judges do not know enough about how computers work to handle disputes about computerized discovery. Some judges may admit that. Justice Souter, for example, recently told a committee of Congress that he was "a computer illiterate" who did not even use a personal computer for opinion writing. ${ }^{119}$ The judicial management theme in discovery reform assumes that judges will be able to handle discovery reliably. ${ }^{120}$ Perhaps if judges are educated and provided a set of form inquiries and orders for their use, the "new" problems of discovery of electronically stored materials will vanish.

\section{$\mathrm{V}$ \\ REFLECTIONS ON CONFRONTING THE PRESENT AND DESIGNING RULES FOR THE FUTURE}

This article began by suggesting that the future has really overtaken the present. If that is correct, it does not mean that something must necessarily be done now. The uncertain question about whether the "new" problems of discovery of electronic material are really so new casts a shadow over proposals for change, particularly radical change. The enduring hoopla of the past quarter century about the burdens, intrusiveness, and general undesirability of conventional discovery at least raises questions about whether the "new" discovery is

117. The ABA Standards suggest the following:

In resolving a motion seeking to compel or protect against the production of electronic information or related software, the court should consider such factors as (a) the burden and expense of the discovery; (b) the need for the discovery; (c) the complexity of the case; (d) the need to protect the attorney-client or attorney work product privilege; (e) whether the information or the software needed to access it is proprietary or constitutes confidential business information; (f) the breadth of the discovery request; and $(\mathrm{g})$ the resources of each party.

ABA STANDARDS, supra note 108 , at 29 b.ii.

118. See MANUAL FOR COMPLEX Litigation, supra note $36, \S \S 21.446,33.12,33.53$.

119. Tony Mauro, Justices Grilled on Minority Clerks, S.F. RECORDER, Mar. 16, 2000, at 1, 11.

120. See supra text accompanying notes $18-25$. 
significantly different. There is considerable reason to pause before making big changes. We must all avoid trying to create the "law of the horse."

Beyond these reasons for inertia, there may be institutional grounds for caution. The discovery rules have been the most amended rules of the last quarter century, and yet another set of amendments has just been adopted. Whether one agrees that creating a permanent committee to review the Federal Rules was the worst thing ever done because the committee would feel obliged to make changes, ${ }^{122}$ one can appreciate that there are times for a rest. Inaction may be all the more attractive in an area where change occurs so quickly. Under the present rule amendment process, the minimum time from initiation of a rule change to completion is about four years. That can be a lifetime in computer developments, so that a change devised now might be irrelevant, and might even be harmful, four years from now.

In some ways, the most intriguing questions raised by recent developments go well beyond the discovery arena and suggest a rethinking of our entire approach to litigation, including substitute methods of trial. Pursuing those possibilities may call into question much we have held sacred, and certainly could not be done with alacrity. Here the generation gap may be real; those who persist in thinking that actual physical presence of witnesses is important to a full appreciation of what they have to say may be replaced by the "wired" cellular phone generation that is more comfortable with electronically transmitted grounds for decisions of all sorts.

Short of remaking litigation in such a fashion, this article suggests many places in the discovery rules in which changes might be suitable for the particular problems presented by the discovery of electronic materials. These are modest measures, and the real questions are whether changes of this sort are needed or would make a useful difference. On these questions, the jury is still out.

It is not at all clear that the generation gap suggested at the outset really exists. To the contrary, the current tumult over discovery of electronic materials seems similar in type and magnitude to the widespread alarm over discovery burdens in the 1970s and 1980s. The kinds of solutions developed in response to the concerns of the 1970s and 1980s may work for this form of discovery as well. Indeed, it may be that the proportionality principle has finally come into its own, and the possibility of substituting electronic inquiry for mind-numbing, page-by-page review of hard copy materials may offer promise of easing, rather than magnifying, discovery burdens in the future.

Two points do seem clear, however. One is that discovery of these sorts of materials must go on. It has already been estimated that some thirty percent of

121. Easterbrook, supra note 38.

122. See Richard L. Marcus, Of Babies and Bathwater: The Prospects for Procedural Progress, 59 BROOK. L. REV. 761, 761 (1993) (quoting Ed Labaton, a prominent lawyer of New York, as stating that creating the Committee was the worst thing ever done for civil litigation). 
all business information is never embodied in hard copy format. ${ }^{123}$ Some report even higher statistics. ${ }^{124}$ Although one may pause to question how that calculation was made, the basic point is that the courts cannot close their eyes to the potential evidentiary significance of that mass of material. The other point is that the vision of discovering "all" information that seems to have animated our predecessors must become passé in the Information Age. Few of us now feel the need for more information. Instead, we need ways to winnow the mass of information and select the part that is really of interest. Computers may be well suited to that task, and sensible behavior by lawyers and judges may be much more useful in harnessing them than any set of rules or guidelines.

123. See Susan J. Silvernail, Electronic Evidence: Discovery in the Computer Age, 58 ALA. LAW. 176, 177 (1997) (estimating that $30 \%$ of business information never appears in hard copy form); Peter V. Lacouture, Discovery and Use of Computer-Based Information in Litigation, 45 R.I.B.J., Dec. 1996, at 9 (estimating that $35 \%$ of corporate communications are never recorded on paper); Pooley \& Shaw, supra note 63, at 58 (citing 1994 estimate that at least $30 \%$ of electronic data never reach hard copy). Of course, there is something of an enigma about which data to count to reach this conclusion.

124. See Ex-Litigator Founds Oakland Legal Services Firm, S.F. RECORDER, May 22, 2000, at 2 (stating that the founder of a legal services firm asserted that "nearly 50 percent of business documents are never printed out"). 
